\title{
Why Does Choice Matter?
}

\author{
Juanito O. Cabanias
}

\section{ABSTRACT}

This study focused on the course and school preference of select high school students, SY 2007-2008 and SY 2018-2019 and answered the following questions: What are the schools and courses preferred by the select high school students from the two batches under study? What are the possible reasons for choosing the school/s and the course/s? What are the factors affecting their decisions? What is the status of the De La Salle Medical and Health Sciences Institute (DLSMHSI) in terms of the level of preference/choice of the respondents from the two batches?; and What is the status of the DLSMHSI in terms of its marketing /positioning / branding? This study involved 1,186 high school students from SY 20172018 and 954 senior high school students from SY 2018-2019. Data collected were treated using frequency count; relative frequency or percentage; and ranking. The study reveals that the High school students are indeed sure enough of the school and the course to take on the whole, their choice of course to pursue depends on its perceived applicability to their chosen career, on the other hand, their choice of school where to complete college education depends on who makes the decision in the family, academic program presentations provided by schools, the features, general image and record of a higher education institution. Finally, DLSMHSI is an institution acceptable to the respondents in terms of pursuing health sciences-related courses.

Keywords: choice, school, course, students.

Published Online: June 19, 2021

ISSN: $2736-4534$

DOI : $10.24018 /$ ejedu.2021.2.3.88

Juanito O. Cabanias

LPT, PhD, De La Salle Medical and

Health Sciences Institute, Philippines.

(e-mail: jocabanias@dlshsi.edu.ph)

*Corresponding Author

\section{INTRODUCTION}

\section{A. Why Does Choice Matter?}

Campbell [1] articulated that Choice is essential for our well-being, as it allows us to feel we have some control over our lives. However, managing too many choices can be detrimental in terms of time, energy and focus. There is a large body of scientific study into choice and decision making, and the route to making good choices is well signposted. According to her, we are on average $22 \%$ more likely to make the (objectively) best choice if we can see all the options at once.

According to the student engagement survey, student choice is listed as one of the most engaging strategies a teacher can allow in the classroom. There is a need to know how to engage students and bring out their best effort. It important to give them a voice in their decisions. This articles further highlights that in a system that can be a flood of top down, there is a need to let classroom be one that allows voices to trickle up. Further, this article emphasizes that in the classrooms, there are brains that will solve the problems of tomorrow. Finally, student choice builds ownership in the learning. Student choice allows students to display their learning in the way that they feel best represents their knowledge. Student choice enforces true differentiation [2].

Knight [3] in his article titled "Why students should choose their own classes", expressed that many students feel that courses they are taking in high school are not relevant to the field of study they would eventually major in at a higher level of education. This is because students according to him are forced to take classes which are deemed unnecessary in the actual field of work. They are just required in order to get their diploma and to graduate. He continued by saying that instead of putting the focus on what really matters, preparing students for the real world and life after high school, students are required to take that take up their effort and time. And as any high school student knows, it is hard to make time for hours of homework while trying to balance their health, a job and sports.

He further explains that the problem with our current education system is that students are spending too much time in classes that will get them nowhere and not enough time in classes that will actually help them in life and their careers.

In conjunction with this, Knight [3] accentuated that students should be able to choose their own classes because it would prepare them better for the real world. Students would have more motivation to learn and come to school if they were given the opportunity to choose their own classes instead of being required to take certain classes in order to graduate. When students have the ability to choose what they would like to learn about, it makes them more eager to engage with the material.

"Real learning thrives when students have real choices," says Huffington Post columnist Blake Boles. "Give high 
school students the same freedom as college students, and we'll take education a step in the right direction."

In the article of Knight also, he elucidated that students only want to take courses that would help them later on in life. Very rarely do students feel they need to take advanced chemistry or calculus because it is going to help them in reallife situations. Most students only want to take courses that will prepare them for the real world. When high schools offer courses like personal finance, public speaking or independent living, students are more willing to take these classes because they know what they take away from these classes will actually help them later on in life. When the students can apply their knowledge learned in high school classes to their real life, that is a successful outcome.

Generally, according to Knight, too many students are failing classes that they should never had to take in the first place.

In the study conducted by Fizer [4] titled Factors Affecting Career Choices of College Students Enrolled in Agriculture, he found out that when students were asked to rate the importance of classes and job skills to their projected careers, biology and communications received the highest overall ratings. Students ranked fine arts and history as the least important. In addition, students ranked time management as the most important job skill and foreign language and international experience as the least important job skills. Also, data from the questionnaire showed that the most influential factor when choosing a major was family (27\%). The next highest factor when choosing a major was a career that is personally rewarding (20\%). Income potential and guidance counselors were considered least important to students when choosing a major.

When asked about their future in agriculture, $89 \%$ of students believe they will work in their area of study. Eightyeight percent believe that there are good to excellent career opportunities in agriculture. In addition, $83 \%$ of students believe that their careers will make a positive impact on the world.

Moreover, the study also presented the factors that influence students when choosing their academic careers, but family was the one factor that had the biggest influence on students in this study. The study concluded that the students who were part of the survey population have a positive outlook about their future agricultural careers and believe they can make a difference in the world.

Most importantly, the article retrieved from https://essay4today.com/blog/what-influences-your-careerchoice stipulated that choosing the future career is perhaps the most important decision in our lives. Therefore, the article emphasized that we have to think well and weigh all the pros and cons. We have to take into account such important factors as: Education; Financial aspects; Work experience; Our personality and interests; and Economic and social conditions of life.

With all of these considerations supported by different literatures and studies, the researcher was motivated to conduct and present a comparative study based on the results of the two related studies done in SY 2007-2008 and SY 2018-2019, which highlighted the schools and courses preferred by the high school students. The researcher conducted two studies with the same objectives but focusing on two different respondents with a time difference of ten (10) years. The results of these two studies served as the bases for the improvement of the marketing programs of the De La Salle Medical and Health Sciences Institute particularly in its positioning and branding strategies. In the first study, the respondents were the graduating students (Grade 10) when the curriculum was not yet Kto12 and in the second study, with the implementation of the Kto12 Curriculum, another 2 years have been added in the basic education program of the students. This became the respondents of the second study.

In determining the aforementioned information, the study also attempted to know the Institute's position or brand as a medical and health sciences institution in the province and in the region and in the country at large; its level of marketability and viability. This undertaking gave the researcher direct responses from the students regarding the status of the Institute's marketing strategies.

\section{Statement of the Problem}

The researcher presented to the Academic Community a comparative study of the course and school preference of the two batches of select high students, SY 2007-2008 and SY 2018-2019.

Specifically, this study answered the following questions:

1) What are the schools and courses preferred by the high school students from the two batches under study?

2) What are the possible reasons for choosing the school/s and the course/s? What are the factors affecting their decisions?

3) What is the status of the DLSMHSI in terms of the level of preference/choice of the respondents from the two batches?

4) What is the status of the DLSMHSI in terms of its marketing /positioning / branding?

\section{THEORETICAL FRAMEWORK}

This study was anchored on Holland's Theory [5]. This theory specifically reiterates the following:

1) In our culture, most people are one of six personality types: Realistic, Investigative, Artistic, Social, Enterprising, and Conventional. Some refer to these as Holland Codes or RIASEC.

2) People of the same personality type working together create a work environment that fits their type. For example, when Artistic persons are together on a job, they create a work environment that rewards creative thinking and behavior - an Artistic environment.

3) There are six basic types of work environments: Realistic, Investigative, Artistic, Social, Enterprising, Conventional. "Work" includes doing things to achieve a purpose, like paid and unpaid jobs, volunteering, sports, or hobbies.

4) People search for environments where they can use their skills and abilities and express their values and attitudes.

For example, Investigative types search for Investigative environments; Artistic types look for Artistic environments, 
and so forth.

5) People who choose to work in an environment similar to their personality type are more likely to be successful and satisfied.

For example, Artistic people are more likely to be successful and satisfied if they choose a job that has an Artistic environment, like choosing to be a dance teacher in a dancing school -- an environment "dominated" by Artistic type people where creative abilities and expression are highly valued.

The conceptual paradigm, Holland's Theory of Career Choice, is presented below to further elucidate the said theory.

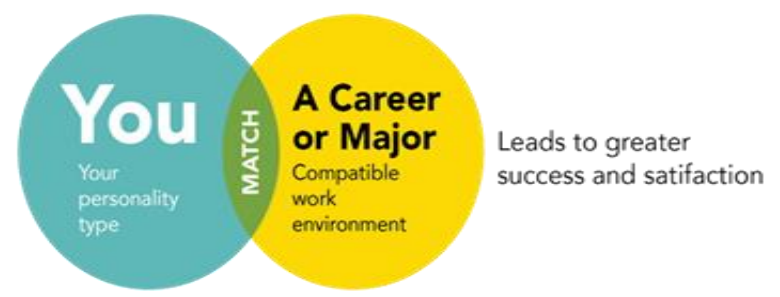

Fig. 1. Holland's Theory of Career Choice.

Source: https://www.careerkey.org/fit/personality/hollands-theory-ofcareer-choice

6) How you act and feel at work depends to a large extent on your workplace (or school) environment.

If you are working with people who have a personality type like yours, you will be able to do many of the things they can do, and you will feel most comfortable with them.

The aforementioned theory clearly relates to the objectives of this study. The initial culmination of one's education is the ability to finish a certain degree in college- a course of his/her choice and at the same time in a school of his/her preference as well. Ideally, the students begin to think and consider all the opportunities, options and offers given by the different academic institutions. There are criteria set by the students in choosing a course or a school. But at the end of the day, there are really innate factors that influence the students in enrolling in a particular program in a particular school [6], [7].

\section{Scope AND Delimitation OF THE StUdy}

This study focused on the comparison between the schools and courses preferred by the select high school students of SY 2007-2008 and SY 2018-2019. It solely depended on: (1) the number of schools visited by the researcher in the conduct of career talks and orientation programs from the different schools in the Cavite, Laguna, Batangas, Rizal, and Quezon (CALABARZON) Provinces and METRO MANILA AREAS in 2007 and (2) the applicants and visitors who visited and inquired (either thru email, social media and other platforms) from the Lasallian Admission and Scholarship Opportunities in 2018. The study being a survey research in nature utilized a particular survey questionnaire as its instrument in eliciting information from the respondents. The identities of the respondents in 2007 and 2018 were not revealed specifically in the second study due to the Data Privacy Policies and Standards. All the responses from the respondents identified were collated and tallied and had been analyzed and interpreted using the appropriate statistical treatment. The data gathering was conducted in July 2007 until March 2008 for the first study and June 2018 until May 2019 for the second study.

\section{REVIEW OF RELATED LITERATURE AND STUDIES}

\section{A. Literatures and Studies Cited}

Ganti and Barnier [8] in their article What is Rational Choice Theory stated that individuals use rational calculations to make rational choices and achieve outcomes that are aligned with their own personal objectives. These results are also associated with an individual's best, selfinterests. Using rational choice theory is expected to result in outcomes that provide people with the greatest benefit and satisfaction given the choices they have available.

In the doctoral of dissertation of Krull [9] titled School Selection Patterns Choice and Traditional Public Schools through the Lenses of Rational Choice Theory and Behavioral Economics Theory, he used rational choice theory and behavioral economics theory to examine parent considerations when selecting an enrollment rich traditional public school (one that grew or sustained enrollment) for their child. Traditional public schools provide children general academic instruction at a school determined by the geographic boundary of their home. For many years, traditional public schools were the dominant publicly funded institution for educating children. However, in the current era of school choice, parents now can select from a variety of educational options. In Milwaukee Public Schools (MPS), traditional public schools compete for students with private voucher schools, inter-district open enrollment schools, magnet/specialty schools, and both non-MPS and MPS charter schools. As a result, traditional public schools struggle to sustain student enrollment. Using the lenses of both rational choice theory and behavior economics theory, this study investigated the characteristics of schools, which parents considered when selecting an enrollment rich traditional public school. Results suggest that participants considered schools with high academics, regardless of income or education level. Additionally, the vast majority of participants considered three or fewer schools. This study contributes to the literature by using both rational choice theory and behavioral economics theory to understand the selection behaviors of parents who choose an enrollment rich traditional public school.

In the study of Penedilla and Rosaldo [10] titled Factors Affecting Career Preferences among Senior High School Students in Tacloban City, they discovered that the senior high school students' choice of career and college degree although mostly are personal choice, is not free from any influence. Their choices, personal or advised or coerced, are affected by multiple factors-from Academic Qualifications to social and economic factors. Therefore, students are motivated in making decision.

To respond to this reality, the Department of Education has even thought of giving the National Career Assessment Examination (NCAE) to determine the apropos courses that should be taken by the students. Although it does not really stop other students from taking the programs, they really 
prefer should they fail in the test. This is also on top of the Kto12 curriculum, whereby the students are given the opportunity to choose the kind of track they want to take e.g., STEM, HUMSS, ABM, TECH-VOC, and among others. In the statistics given by the Commission on Higher Education [11], the top three (3) courses that the graduating students prefer to take are the following: Nursing, Information Technology and Hotel and Restaurant Management. These courses have been considered the most in-demand for the past several years. In fact, most of the graduates of these courses are working overseas [6], [7].

In the statistics of De La Salle Medical and Health Sciences Institute in 2018, the BS Nursing program still emerges as the number one (1) course preferred by the students. This was affirmed in the number of sections allotted for the program. Compared to other undergraduate health sciences courses, the Nursing program gets the biggest share in the pie with a total of six (6) sections with forty-five (45) students per section (2018 Enrollment Statistics [12], The Registrar as cited in Cabanias [7]).

On September 20, 2008, GMA 7's youth-oriented show "Ka-blog" conducted a survey at the University belt in Metro Manila regarding the course most preferred by students. Monica, one of the hosts of the program, revealed that for 2008, BS Nursing is still the most in-demand course for graduating students. Factors affecting this choice are parents' decision, personal choice and peer pressures. In fact, even during the initial implementation of the Kto12 curriculum, when all schools had zero enrollment, DLSMHSI still managed to have 2 sections for its BS Nursing program [6].

In the researcher's experience in administering the Student Admissions Test of De La Salle University-Dasmarinas when he was still the Director for Admissions, (SY 20042005 to SY 2007-2008) and as a Concurrent Director for Lasallian Admission and Scholarship Opportunities (SY2008-2009 up to present), most of the examinees from the Middle East regions preferred Nursing and other allied health sciences courses. Factors relating to this are: very in demand in the Middle East, their parents are also nurses, high-paying profession, opportunities to migrate to other countries particularly in North America and European countries, and the like [7].

In relation to this, based on the Higher Education facts and figures released by CHED, the top five disciplines in terms of enrollment for academic year (AY) 2016-17 are: (1) Business Administration-Related with 921,324 enrollees; (2) Education and Teacher Training with 740,713; (3) Engineering and Technology with 448,550; (4) Information and Technology with 398,765, and Medical-Allied with 203,561 [13].

However, the researcher believes that the courses, being in demand, should not lax any higher institutions, the Admissions Office/Marketing Office for that matter, in terms of its marketing. The courses may be in demand, but this may be affected by the inability of the schools to market the program to the fullest. The schools are now the target of the would-be college students. They have already identified the program or the course they want to take, and now it is high time for them to choose the best schools. There are factors/considerations affecting their schools of choice. Among them are quality education; high end facilities; safe and very conducive for learning; globally competitive teaching workforce; well-known throughout the country and abroad; good performance rating in the board exams; high employment rate of graduates; and the like [6], [7].

Based on DLSMHSI's experience so far, as early as September, a number of schools have already invited the Lasallian Admissions and Scholarship Opportunities for virtual career talks and orientation programs. The virtual activities are being done now because of the current pandemic where face to face career talks and orientation programs would not be feasible. From the list LASO has, majority of the schools are coming from METRO MANILA and CALABARZON areas. Surprisingly, the Institute has also been receiving invites from the different schools in Northern Luzon, Bicol Region, Visayas, and Mindanao. Given the situation the country and the world have, schools really have to come up with different creative initiatives to be able to reach out to the students so these potential individuals shall be given the necessary information and data that would help them decide what courses to take and where to take them.

Having considered all of these, the researcher ventured into this kind of research endeavor, a comparative study in particular, to be able to present to the Academic Community of DLSMHSI the course and school preference of the two batches of students (SY 2007-2008 and SY 2018-2019).

\section{METHODS AND PROCEDURES}

\section{A. Research Design}

This study utilized the descriptive research survey technique. A survey is a non-experimental, descriptive research method. Surveys can be useful when a researcher wants to collect data on phenomena that cannot be directly observed (such as opinions) (http://www.gslis.utexas.edu/ palmquis/courses/survey.htm 1 as cited in Cabanias [6], [7]).

A survey is a means of gathering information about a particular population by sampling some of its members, usually through a system of standardized questions. It can be conducted by mail, telephone, personal interview, or internet It can be administered either to individuals or groups. Questions may be related to behaviors, beliefs, attitudes and/or characteristics of those who are surveyed. The aforementioned research technique was employed in this study considering that the purpose of a survey is to elicit information which, after evaluation, results in a profile or statistical characterization of the population sampled (http://www.fairfaxcounty.gov/demogrph/pdf/questionnaire design.pdf as cited in Cabanias [6], [7]).

\section{B. Respondents of the Study}

This study involved one thousand one hundred eighty-six $(1,186)$ graduating high school students from SY 2017-2018 and nine hundred fifty-four (954) senior high school students from SY 2018-2019. They were selected following the purposive sampling strategy as only those graduating high school students from the schools visited by the researcher in the course of his school visit for career talks and orientation programs in SY 2007-2008 and those senior high school graduating students who visited the Lasallian Admission and 
Scholarship Opportunities and who inquired on-line, and emails were deliberately included in the sampling frame for this research. The profiles of the respondents in terms of select classificatory variables are presented below.

TABLE I: PROFILE OF THE RESPONDENT HigH SCHOOL STUDENTS IN TERMS OF AGE

\begin{tabular}{ccccc}
\hline \multirow{2}{*}{ Age in years } & \multicolumn{3}{c}{ SY 2007-2008 } & \multicolumn{2}{c}{ SY 2018-2019 } \\
\cline { 2 - 5 } & Frequency & Percent & Frequency & Percent \\
\hline 14 & 78 & 6.58 & & \\
15 & 635 & 53.54 & & \\
16 & 396 & 33.39 & & \\
17 & 51 & 4.30 & & \\
18 \& Above & 26 & 2.19 & & 1.78 \\
16 \& Below & & & 17 & 31.24 \\
17 & & & 298 & 58.07 \\
18 & & & 554 & 8.91 \\
19 \& Above & & & 85 & $\mathbf{1 0 0 . 0 0}$ \\
TOTAL & $\mathbf{1 1 8 6}$ & $\mathbf{1 0 0}$ & $\mathbf{9 5 4}$ & \\
\hline
\end{tabular}

Going over Table I, SY 2007-2008, it can be noted that the ages of the respondents ranged from 14 to more than 18 years old. Further examination of the same tabular data reveals that most of them were 15 years old when the survey was conducted, based on the frequency distribution of 635 or $53.54 \%$.

While in Table Ш, SY 2018-2019, it can be noted that the ages of the respondents ranged from 16 to more than 19 years old. Further examination of the same tabular data reveals that most of them were 18 years old when the survey was conducted, based on the frequency distribution of 554 or $58.07 \%$.

TABLE II: PROFILE OF THE RESPONDENT HIGH SCHOOL STUDENTS IN TERMS OF ADDRESS

\begin{tabular}{ccccc}
\multicolumn{5}{c}{ TERMS OF ADDRESS } \\
\hline \multirow{2}{*}{ Place of residence } & \multicolumn{2}{c}{ SY 2007-2008 } & \multicolumn{2}{c}{ SY 2018-2019 } \\
\cline { 2 - 5 } & Frequency & Percent & Frequency & Percent \\
\hline Dasmariñas & 133 & 11.21 & & \\
Cavite & 528 & 44.52 & 443 & 46.44 \\
Laguna & 127 & 10.71 & 75 & 7.86 \\
Batangas & 225 & 18.97 & 61 & 6.39 \\
Rizal & & & 12 & 1.26 \\
Manila & 85 & 7.17 & 181 & 18.98 \\
Quezon & 88 & 7.42 & 3 & 0.31 \\
Other Luzon Areas & & & 15 & 1.57 \\
Visayas and & & & 18 & 1.89 \\
Mindanao Areas & & & 23 & 2.41 \\
Outside Philippines & & & 123 & 12.89 \\
Not Specified & & $\mathbf{1 0 0}$ & $\mathbf{9 5 4}$ & $\mathbf{1 0 0 . 0 0}$ \\
TOTAL & $\mathbf{1 1 8 6}$ & $\mathbf{1 0 0}$
\end{tabular}

As regards the addresses of the respondents from SY 2007-2008, 133 or $11.21 \%$ were residing at Dasmariñas, while 127 or $10.71 \%$ were from Laguna. Two-hundred twenty-five (225) or $18.97 \%$ were from Batangas, while 85 or $7.17 \%$ were from Manila. Further examination of the same tabular data shows that 88 or $7.42 \%$ were from Quezon. Nonetheless, most of them were residents of Cavite based on the frequency distribution of 528 or $44.52 \%$.

For SY 2018-2019, the addresses of the respondents show that 443 or $46.44 \%$ are residing in Cavite, while 181 or $18.98 \%$ are from Metro Manila. Seventy-five (75) are residing in Laguna, 61 in Batangas, and other small numbers in Rizal, Quezon, other areas in Luzon, Visayas, and Mindanao. A significant number of 123 or $12.89 \%$ have not indicated their addresses. Nonetheless, most of them are residents of Cavite based on the frequency distribution and percentage presented. The data are the same with SY 20072008, as reflected in this section.
Table III displays the profile of the respondents in terms of religion.

Generally, it can be noted in Table III, SY 2007-2008, that the religions of the respondents were diverse. Some were INC and Born-Again Christians. Nonetheless, majority of the respondents were Catholics. This finding was based on the frequency distribution of 1033 or $87.10 \%$. Similarly, it can be noted in Table III, SY 2018-2019 majority of the respondents are Catholics. This finding is based on the frequency distribution of 787 or 82.49 .

TABLE III: PROFILE OF THE High SCHOOL STUdENTS IN TERMS OF

\begin{tabular}{ccccc} 
& \multicolumn{3}{c}{ RELIGION } & \\
\hline \multirow{2}{*}{ Religion } & \multicolumn{2}{c}{ SY 2007-2008 } & \multicolumn{2}{c}{ SY 2018-2019 } \\
\cline { 2 - 5 } & Frequency & Percent & Frequency & Percent \\
\hline Catholic & 1033 & 87.10 & 787 & 82.49 \\
INC & 20 & 1.69 & & \\
Born Again & 89 & 7.50 & & \\
Others & 44 & 3.71 & & \\
Non-Catholic & & & 298 & 16.67 \\
Not Specified & & & 554 & 0.84 \\
TOTAL & $\mathbf{1 1 8 6}$ & $\mathbf{1 0 0}$ & $\mathbf{9 5 4}$ & $\mathbf{1 0 0 . 0 0}$ \\
\hline
\end{tabular}

Displayed in Table IV is the profile of the respondents in terms of gender for two batches. A close examination of tabular data (SY 2007-2008) shows that 549 of the respondents or $46.29 \%$ were males. Majority of the respondents, however, were females based on the frequency distribution of 637 or 53.71 .

TABLE IV: PROFILE OF THE RESPONDENT HIGH SCHOOL STUDENTS IN

\begin{tabular}{ccccc}
\hline \multirow{2}{*}{ Gender } & \multicolumn{3}{c}{ TERMS OF GENDER } \\
\cline { 2 - 3 } & \multicolumn{2}{c}{ SY2007-2008 } & \multicolumn{2}{c}{ SY 2018-2019 } \\
\cline { 2 - 5 } Mrequency & Percent & & Frequency & Percent \\
\hline Female & 549 & 46.29 & 266 & 27.88 \\
Not & 637 & 53.71 & 684 & 71.70 \\
Specified & & & 4 & 0.84 \\
TOTAL & $\mathbf{1 1 8 6}$ & $\mathbf{1 0 0}$ & $\mathbf{9 5 4}$ & $\mathbf{1 0 0 . 0 0}$ \\
\hline
\end{tabular}

The tabular data (SY 2018-2019) show that 266 of the respondents or $27.88 \%$ are males. Majority of the respondents, however, are also females based on the frequency distribution of 684 or $71.70 \%$.

Presented in Table $\mathrm{V}$ is the profile of the respondents in terms of nationality.

Data show that $191.60 \%$ of the respondents from SY 2007-2008 had dual citizenship, while 13 or $1.10 \%$ were foreigners. Nonetheless, most of them were Filipinos as indicated by the frequency distribution of 1154 or $97.30 \%$. As regards SY 2018-2019, the data show that $0.73 \%$ of the respondents have dual citizenship, while 10 or $1.05 \%$ belong to other nationalities. As expected, most of them are Filipinos, as indicated by the frequency distribution of 924 or $96.86 \%$.

TABLE V: PROFILE OF THE RESPONDENT HIGH SCHOOL STUDENTS IN TERMS OF NATIONALITY

\begin{tabular}{|c|c|c|c|c|}
\hline \multirow{2}{*}{ Nationality } & \multicolumn{2}{|c|}{ SY 2007-2008 } & \multicolumn{2}{|c|}{ SY 2018-2019 } \\
\hline & Frequency & Percent & Frequency & Percent \\
\hline Filipino & 1154 & 97.30 & 924 & 96.86 \\
\hline Dual citizenship & 19 & 1.60 & 7 & 0.73 \\
\hline Foreigner & 13 & 1.10 & & \\
\hline $\begin{array}{c}\text { Other } \\
\text { Nationalities }\end{array}$ & & & 10 & 1.05 \\
\hline Not Specified & & & 13 & 1.36 \\
\hline TOTAL & 1186 & 100 & 954 & 100.00 \\
\hline
\end{tabular}


The next tabular presentation displays the profile of the respondents in terms of their year level in Senior High School.

TABLE VI: PROFILE OF THE RESPONDENT High SCHOOL STUDENTS IN TERMS OF YEAR LEVEL

\begin{tabular}{ccc}
\multicolumn{3}{c}{ SY 2018-2019 } \\
\hline Gender & Frequency & Percent \\
\hline Grade 12 & 518 & 54.30 \\
Grade 11 & 3 & 0.31 \\
Not Specified & 433 & 45.39 \\
TOTAL & $\mathbf{9 5 4}$ & $\mathbf{1 0 0 . 0 0}$ \\
\hline
\end{tabular}

A perusal of Table VI reveals that 433 or $45.39 \%$ of the respondents have not specified their year level. However, more than $50 \%$ of the respondents are in Grade 12 with 518 students or $54.30 \%$. It can be seen in this section that there is no presentation of data for SY 2007-2008. This is because all the respondents from SY 2007-2008 were all in Grade 10.

Shown in Table VII is the profile of the respondents in terms of rank in the family.

In terms of rank, 108 or $9.11 \%$ was either the only son or daughter, while 294 or $24.79 \%$ were in the middle rank. Three hundred forty (340) or $28.67 \%$ were the youngest in their family, while majority of the respondents were the eldest in their family.

TABLE VII: PROFILE OF THE RESPONDENT HIGH SCHOOL STUDENTS IN TERMS OF RANK IN THE FAMILY

\begin{tabular}{|c|c|c|c|c|}
\hline \multirow{2}{*}{$\begin{array}{c}\text { Rank in the } \\
\text { family }\end{array}$} & \multicolumn{2}{|c|}{ SY 2007-2008 } & \multicolumn{2}{|c|}{ SY 2018-2019 } \\
\hline & Frequency & Percent & Frequency & Percent \\
\hline Eldest & 444 & 37.44 & 348 & 36.48 \\
\hline Middle & 294 & 24.79 & 181 & 18.97 \\
\hline Youngest & 340 & 28.67 & 292 & 30.61 \\
\hline $\begin{array}{c}\text { Only } \\
\text { Son/Daughter }\end{array}$ & 108 & 9.11 & 113 & 11.84 \\
\hline $\begin{array}{c}\text { Not Specified } \\
\text { TOTAL }\end{array}$ & 1186 & 100 & $\begin{array}{c}20 \\
954\end{array}$ & $\begin{array}{c}2.10 \\
\mathbf{1 0 0 . 0 0}\end{array}$ \\
\hline
\end{tabular}

In terms of rank of the respondents from SY 2018-2019, 113 or $11.84 \%$ are either the only son or daughter, while 181 or $18.97 \%$ are in the middle rank. Two hundred ninety-two (292) or $30.61 \%$ are the youngest in the family, while majority of the respondents are the eldest in their family with 348 respondents or $36.48 \%$.

Table VIII displays the profile of the respondents in terms of their fathers' educational attainment.

TABLE VIII: PROFILE OF THE RESPONDENT HIGH SCHOOL STUDENTS IN TERMS OF THEIR FATHERS' EDUCATIONAL ATTAINMENT

\begin{tabular}{ccccc}
\hline $\begin{array}{c}\text { Father's } \\
\text { educational } \\
\text { attainment }\end{array}$ & \multicolumn{2}{c}{ SY 2007-2008 } & \multicolumn{2}{c}{ SY 2018-2019 } \\
\cline { 2 - 5 } & Frequency & Percent & Frequency & Percent \\
\hline Undergraduate & 414 & 34.91 & 191 & 20.02 \\
College Graduate & 732 & 61.72 & 599 & 62.79 \\
Master's Degree & 35 & 2.95 & 51 & 5.35 \\
Doctorate Degree & 5 & 0.42 & 17 & 1.78 \\
Vocational & & & 10 & 1.05 \\
Not Specified & & & 86 & 9.01 \\
TOTAL & $\mathbf{1 1 8 6}$ & $\mathbf{1 0 0}$ & $\mathbf{9 5 4}$ & $\mathbf{1 0 0 . 0 0}$ \\
\hline
\end{tabular}

Survey revealed that the educational attainment of the respondents' fathers from SY 2007-2008 was diverse. Four hundred fourteen (414) or $34.91 \%$ reported that their fathers were college undergraduates, while 35 or $2.95 \%$ were holders of master's degrees. There were five (5) of the respondents or $0.42 \%$ whose fathers were doctorate degree holders. Nonetheless, majority of the respondents' fathers were college graduates based on the frequency distribution of 732 or $61.72 \%$.

Looking at the data presented, the survey reveals that the educational attainment of the respondents' fathers from SY 2018-2019 is diverse also. One hundred ninety-one (191) or $20.02 \%$ have reported that their fathers are college undergraduates, while 51 or $5.35 \%$ are holders of masters' degrees. There are seventeen (17) of the respondents or $1.78 \%$ whose fathers are doctorate degree holders. Ten (10) or $1.05 \%$ have mentioned that their fathers finished vocational courses, and 86 or $9.01 \%$ have not specified their fathers' educational attainment. Nonetheless, majority of the respondents' fathers are college graduates based on the frequency distribution of 599 or $62.79 \%$. This is a similar finding, as seen in the data from SY 2007-2008.

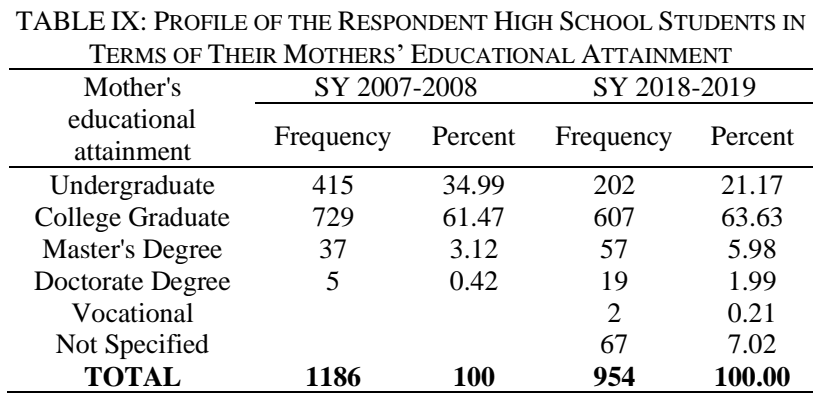

Going over Table IX, SY 2007-2008, it can be noted that 415 or $34.99 \%$ of the respondents reported that their mothers were college undergraduates, while 37 or $3.12 \%$ claimed that their mothers were master's degree holders. There were 5 or $0.42 \%$ who averred that their mothers completed doctorate degrees. Nonetheless, majority of the respondents' mothers were college graduates based on the frequency distribution of 729 or $61.47 \%$.

As regards Table IX, SY 2018-2019, it can be noted that 202 or $21.17 \%$ of the respondents have reported that their mothers are college undergraduates, 2 or $0.21 \%$ under vocational courses, while 57 or $5.98 \%$ have claimed that their mothers are masters' degree holders. There are 19 or $1.99 \%$ who averred that their mothers completed doctorate degrees. Sixty-seven (67) of the total respondents have not specified their mothers' educational attainment. Nonetheless, majority of the respondents' mothers are college graduates based on the frequency distribution of 607 or $63.63 \%$. Both the respondents' mothers from SY 2007-2008 and SY 20182019 are college graduates.

\section{RESEARCH INSTRUMENT}

Data for this study were collected with the use of a researcher-made and validated survey questionnaire. The questionnaire is a structured technique for collecting primary data in a marketing survey. It is a series of written or verbal questions for which the respondents provide answers (Quick MBA, Marketing, Knowledge to Power Your Business/www.quickmba.com/marketing/research/design/2 008). This questionnaire consists of two parts.

Part 1 was designed to elicit data on the personal information of the respondents. Notable among the variables included in this portion of the survey questionnaire were the following: age; address, gender; religion; father's educational attainment; and mother's educational attainment. 
Part 2 of the instrument is the survey questionnaire itself. This portion of the instrument solicited responses to the following questions/items; possible reasons for choosing the course/s; top three school choices for health sciences program; top three course choices; question on who decides on what course and school of choice; source of information about DLSMHSI; what people say about DLSMHSI; features they look for in a college; top three choices among the schools where the respondents applied for admissions; most effective medium of introducing one school which helps the respondents where to study; schools that gave presentations/career talks in their school; question on whether presentations motivated/encouraged them to take up health science course; option to study at DLSMHSI; and their one-word description of DLSMHSI [6], [7].

\section{DATA GATHERING PROCEDURE}

For Batch 2007-2008, the survey questionnaire was administered by the researcher in the course of his career talk/presentation and for Batch 2018-2019, the survey questionnaire was distributed to all visitors who visited the Lasallian Admission and Scholarship Opportunities and who have applied for admissions at the De La Salle Medical and Health Sciences Institute and those who emailed and inquired on-line.

\section{Statistical Treatment OF DATA}

In order to come up with meaningful profile of the respondents relative to their personal information and their preferred course and school, the following descriptive statistical techniques were applied: frequency count; relative frequency or percentage; and ranking.

\section{RESUlTS AND DisCUSSIONS}

This presents the data gathered to respond systematically to the questions posed in the study. It is divided into the following areas of inquiry: possible reasons for choosing the course/s; top three school choices for health sciences program; top three course choices; question on who decides on what course and school of choice; source of information about DLSMHSI; what people say about DLSMHSI; features they look for in a college; top three choices among the schools where the respondents applied for admissions; most effective medium of introducing one school which helps the respondents where to study; schools that gave presentations/career talks in their school; question on whether presentations motivated/encouraged them to take up health science course; option to study at DLSMHSI; and their one-word description of DLSMHSI; and status of DLSMHSI in terms of its marketing/positioning/branding.

\section{SchoOls AND COURSES PREFERRED By High SCHOOL STUDENTS}

Presented in Table $X$ are the schools of choice of the respondent high school students, SY 2007-2008 and SY 2018-2019. Going over Table X (SY 2007-2008), it can be noted that ranked one among the schools preferred by the respondents was De La Salle Health Sciences Institute (DLSHSI) based on the frequency distribution of 300 or $25.30 \%$. Ranked second among the preferred school was University of the Philippines UP), with a frequency distribution of 266 or $22.43 \%$. Next in rank were the following higher education institutions from CALABARZON and METRO MANILA: University of Sto. Tomas (UST) (260 or 21.92\%); Adamson University (AU) (158 or $13.32 \%$ ); Far Eastern University (FEU) (59 or $4.97 \%$ ); other schools not in the list (57 or 4.8\%); and Ateneo De Manila University (ADMU) (50 or $4.22 \%$ ). Least preferred by the respondents, however, was Philippine Christian University (PCU) with a frequency distribution of 36 or $3.04 \%$.

TABLE X: SCHOOLS OF CHOICE OF THE RESPONDENT HIGH SCHOOL

\begin{tabular}{|c|c|c|c|c|c|c|}
\hline \multirow{2}{*}{$\begin{array}{c}\text { Preferred } \\
\text { schools }\end{array}$} & \multicolumn{3}{|c|}{ SY 2007-2008 } & \multicolumn{3}{|c|}{ SY 2018-2019 } \\
\hline & Frequency & Percent & Rank & Frequency & Percent & Rank \\
\hline DLSHSI & & & & & & \\
\hline $\begin{array}{c}/ \\
\text { DLSMH } \\
\text { SI }\end{array}$ & 300 & 25.30 & 1 & 220 & 23.06 & 1 \\
\hline UP & 266 & 22.43 & 2 & 189 & 19.81 & 2 \\
\hline ADMU & 50 & 4.22 & 7 & & & \\
\hline UST & 260 & 21.92 & 3 & 170 & 17.82 & 3 \\
\hline $\mathrm{AU}$ & 158 & 13.32 & 4 & & & \\
\hline FEU & 59 & 4.97 & 5 & 95 & 9.97 & 5 \\
\hline PCU & 36 & 3.04 & 8 & & & \\
\hline Others & 57 & 4.81 & 6 & & & \\
\hline DLSU-D & & & & 125 & 13.10 & 4 \\
\hline UE & & & & 67 & 7.02 & 6 \\
\hline $\mathrm{CEU}$ & & & & 23 & 2.41 & 7 \\
\hline EAC & & & & 21 & 2.20 & 8 \\
\hline LPU & & & & 19 & 1.99 & 9 \\
\hline PLM & & & & 15 & 1.57 & 10 \\
\hline $\begin{array}{c}\text { Not } \\
\text { Specified }\end{array}$ & & & & 10 & 1.05 & 11 \\
\hline TOTAL & 1186 & 100.0 & & 954 & 100.00 & \\
\hline
\end{tabular}

For SY 2018-2019, it can be noted that ranked one among the schools preferred by the respondents was DLSMHSI based on the frequency distribution of 220 or $23.06 \%$. Ranked second among the preferred school was UP, with a frequency distribution of 189 or $19.81 \%$. Next in rank were the following higher education institutions: UST (170 or 17.82\%); De La Salle University-Dasmariñas (DLSU-D) (125 or $13.10 \%$ ); FEU (95 or $9.97 \%$ ); University of the East (UE) (67 or 7.02\%); Centro Escolar University (CEU) (23 or $2.41 \%$ ); Emilio Aguinaldo College (EAC) (21 or 2.20\%); Lyceum of the Philippines University (LPU) (19 or 1.99\%); Pamantasan ng Lungsod ng Maynila (PLM) (15 or 1.57\%); and other schools not specified (10 or $1.05 \%)$. The results from both SY 2007-2008 and SY 2018-2019 show that DLSMHSI ranked one among the schools preferred by the respondents.

Displayed in Table XI are the preferred courses of the respondent high school students, SY 2007-2008 and SY 2018-2019.

A cursory examination of tabular data from SY 2007-2008 show that Hotel and Restaurant Management (HRM) ranked first among the courses preferred by the respondents, based on the frequency distribution of 398 or $33.56 \%$. Second in rank was business-related course as indicated by the frequency distribution of 246 or $20.74 \%$. Third rank among the courses preferred by the respondents was engineering, 
based on the frequency distribution of 189 or $15.94 \%$. The other courses preferred by the same group of respondents as ranked were the following: health sciences (150 or $12.65 \%$ ); information technology (100 or $8.53 \%)$; liberal arts (66 or $5.56 \%$ ); education (34 or 2.87\%); and courses not in the listing (3 or $0.25 \%)$.

\begin{tabular}{|c|c|c|c|c|c|c|}
\hline \multirow{2}{*}{ Preferred courses } & \multicolumn{3}{|c|}{ SY 2007-2008 } & \multicolumn{3}{|c|}{ SY 2018-2019 } \\
\hline & Frequency & Percent & Rank & Frequency & Percent & Rank \\
\hline Health Sciences & 150 & 12.65 & 4 & & & \\
\hline Business & 246 & 20.74 & 2 & & & \\
\hline Liberal Arts & 66 & 5.56 & 6 & & & \\
\hline Information Technology & 100 & 8.43 & 5 & & & \\
\hline Education & 34 & 2.87 & 7 & & & \\
\hline Engineering & 189 & 15.94 & 3 & & & \\
\hline HRM & 398 & 33.56 & 1 & & & \\
\hline Others & 3 & 0.25 & 8 & & & \\
\hline Nursing & & & & 150 & 15.72 & 1 \\
\hline Medical Technology & & & & 147 & 15.41 & 2 \\
\hline Physical Therapy & & & & 132 & 13.84 & 3 \\
\hline Pharmacy & & & & 94 & 9.85 & 4 \\
\hline Radiologic Technology & & & & 92 & 9.64 & 5 \\
\hline $\begin{array}{c}\text { Other Courses (Humanities, Business, } \\
\text { Engineering) }\end{array}$ & & & & 75 & 7.86 & 6 \\
\hline Occupational Therapy & & & & 70 & 7.34 & 7 \\
\hline Other Allied Health Courses (Veterinary & & & & & & \\
\hline $\begin{array}{c}\text { Medicine, Medical and Human Biology, } \\
\text { Nuclear Medicine, Biotechnology, } \\
\text { Dentistry) }\end{array}$ & & & & 60 & 6.29 & 8 \\
\hline Not Specified & & & & 49 & 5.14 & 9 \\
\hline Speech and Language Pathology & & & & 47 & 4.93 & 10 \\
\hline Biochemistry & & & & 38 & 3.98 & 11 \\
\hline TOTAL & 1186 & 100 & & 954 & 100 & \\
\hline
\end{tabular}

Apparently, HRM was on top of the courses preferred by respondent high school students during SY 2007-2008. Their preference for HRM could probably be attributed to the perceived employability of those who finish this course.

However, for SY 2018-2019, the tabular data show that Nursing ranked first among the courses preferred by the respondents, based on the frequency distribution of 150 or $15.72 \%$. Second in rank was Medical Technology, as indicated by the frequency distribution of 147 or $15.41 \%$. Third rank among the courses preferred by the respondents was Physical Therapy, based on the frequency distribution of 132 or $13.84 \%$. The other courses preferred by the same group of respondents as ranked were the following: Pharmacy (94 or 9.85\%); Radiologic Technology (92 or 9.64\%); Other Courses (Humanities, Business and Engineering (75 or $7.86 \%$ ); Occupational Therapy (70 or 7.34\%); Other Allied Health Courses (Veterinary Medicine, Medical and Human Biology, Nuclear Medicine, Biotechnology, Dentistry) (60 or 6.29\%); Speech and Language Pathology (47 or $4.93 \%$ ); Biochemistry (38 or $3.98 \%$ ); and other courses not specified (49 or $5.14 \%$ ).
Apparently, Nursing is on top of the courses preferred by respondent senior high school students. Their preference for Nursing could probably be attributed to the perceived employability in overseas of those who finished this course.

\section{Possible ReAsons FOR CHOOSING THE SCHOOL AND the Course}

Displayed in Table XII, SY 2007-2008, are reasons given by the respondents for choosing their preferred courses to pursue right after graduation from high school.

A closer look at Table XII shows that ranked one among the reasons for choosing their preferred courses was the applicability to their chosen career. This was substantiated by the frequency distribution of 317 or $26.73 \%$. Second in rank among the reasons given by the respondents was high paying job opportunities, as indicated by the frequency distribution of 300 or $25.30 \%$. This was followed by the reason, in demand abroad, with a frequency distribution of 275 or $23.19 \%$. The other reasons stated by the respondent high school students as ranked were the following: influenced by parents (109 or $9.19 \%$ ); affordable by nature (96 or $8.09 \%$ ); and influenced by friends ( 89 or $7.50 \%)$.

TABLE XII: REASONS GIVEN BY THE RESPONDENT HIGH SCHOOL STUDENTS FOR CHOOSING THEIR PREFERRED COURSES

\begin{tabular}{ccccccc}
\hline Reasons for choosing the & \multicolumn{3}{c}{ SY 2007-2008 } & \multicolumn{3}{c}{ SY 2018-2019 } \\
\cline { 2 - 7 } course & Frequency & Percent & Rank & Frequency & Percent & Rank \\
\hline $\begin{array}{c}\text { Applicability to my } \\
\text { chosen career/path }\end{array}$ & 317 & 26.73 & 1 & 720 & 75.47 & 1 \\
$\quad \begin{array}{c}\text { High paying job } \\
\text { opportunities }\end{array}$ & 300 & 25.30 & 2 & 53 & 5.56 & 4 \\
Influenced by parents & 109 & 9.19 & 4 & 76 & 7.97 & 2 \\
Affordable by nature & 96 & 8.09 & 5 & 3 & 0.31 & 7 \\
$\quad \begin{array}{l}\text { Influenced by } \\
\text { friends/peers/classmates }\end{array}$ & 89 & 7.50 & 6 & 15 & 1.57 & 6 \\
In demand abroad & 275 & 23.19 & 3 & 56 & 5.87 & 3 \\
$\quad \begin{array}{c}\text { Not specified } \\
\text { TOTAL }\end{array}$ & $\mathbf{1 1 8 6}$ & $\mathbf{1 0 0}$ & & $\mathbf{9 5 4}$ & $\mathbf{1 0 0}$ & 5 \\
\hline
\end{tabular}


For SY 2018-2019, the table show that ranked one among the reasons for choosing their preferred courses was the applicability to their chosen career also. This was substantiated by the frequency distribution of 720 or $75.47 \%$. Second in rank among the reasons given by the respondents was influenced by parents, as indicated by the frequency distribution of 76 or $7.97 \%$. This was followed by the reason, in demand abroad, with a frequency distribution of 56 or $5.87 \%$. The other reasons stated by the respondent senior high school students as ranked were the following: High Paying Job Opportunities (53 or 5.56\%); Influenced by friends/peers/classmates (15 or $1.57 \%$ ); and affordable by nature $(3$ or $0.31 \%)$. Included in the list are those not specified by the respondents with a total of 31 or $3.25 \%$. The aforesaid findings are supported by the study conducted by Fizer [4] titled Factors Affecting Career Choices of College Students Enrolled in Agriculture. The data from the questionnaire showed that the most influential factor when choosing a major was family $(27 \%)$. The next highest factor when choosing a major was a career that is personally rewarding (20\%). Income potential and guidance counselors were considered least important to students when choosing a major. This is further supported by the Holland's Theory of Personality which states that people who choose to work in an environment similar to their personality type are more likely to be successful and satisfied.

Some of the factors that contributed to their choice of school are presented in the next set of tabular presentations. These factors include the following: the decision maker on where to study; presentations given prior to graduation by college authorities; and features students look for in college.

Table XIII shows the data on who makes the decision as regards choice of college on the part of the respondent high school students, SY 2007-2008 and SY 2018-2019.

As reflected in Table XIII, SY 2007-2008, 131 of the respondents or $11 \%$ claimed that their father was the one deciding on where they should study. On the other hand, 158 or $13.3 \%$ claimed that their mother was the one making the decision for them. Eighteen (18) among them or $1.5 \%$ reported that other siblings in their family decide for them, while one (1) reported others doing it for him. Nonetheless, more than half of the respondents asserted that they, themselves, make the decision on where to pursue their lifetime goal after college. This finding was substantiated by the frequency distribution of 878 or 74 .

TABLE XIII: DISTRIBUTION OF THE RESPONDENT HIGH SCHOOL STUDENTS IN TERMS OF WHO MAKES THE DECISION AS REGARDS SCHOOLS OF CHOICE

\begin{tabular}{ccccccc}
\multicolumn{7}{c}{ Who } \\
\cline { 2 - 7 } $\begin{array}{c}\text { makes } \\
\text { decision }\end{array}$ & Frequency & Percent & Rank & Frequency & Percent & Rank \\
\hline Father & 131 & 11.0 & 3 & 41 & 4.30 & 4 \\
Mother & 158 & 13.3 & 2 & 80 & 8.39 & 2 \\
Siblings & 18 & 1.5 & 4 & & & \\
Yourself & 878 & 74.0 & 1 & 747 & 78.30 & 1 \\
Others & 1 & 0.1 & 5 & & & \\
Family & & & & 63 & 6.60 & 3 \\
Not & & & & 18 & 1.89 & 5 \\
specified & $\mathbf{1 1 8 6}$ & $\mathbf{1 0 0}$ & & $\mathbf{9 5 4}$ & $\mathbf{1 0 0}$ & \\
TOTAL & & & & & & \\
\hline
\end{tabular}

Table XIII, SY 2018-2019 shows that 747 of the respondents or $78.30 \%$ claimed that they themselves were the ones deciding on where they should study. On the other hand, 80 or $8.39 \%$ claimed that their mother was the one making the decision for them. Sixty-three (63) among them or $6.63 \%$ reported that their family decide for them, while forty-one (41) reported their fathers doing it for them. A total of 18 or $1.89 \%$ did not specify who makes the decision as regards their school of choice. Nonetheless, more than three fourths of the respondents asserted that they themselves make the decision on where to pursue their lifetime goal after senior high school. This finding was substantiated by the frequency distribution of 747 .

This goes to show that the respondents belonged to families that adhere to the belief that their children should be responsible enough to make decisions for themselves. This also affirms the findings in the study conducted by Penedilla and Rosaldo [10] titled Factors Affecting Career Preferences among Senior High School Students in Tacloban City. They discovered that the senior high school students' choice of career and college degree although mostly are personal choice, is not free from any influence.

Another factor that can explain the respondents' choice of school where to study was the presentation given by reputable Higher Education Institutions (HEIs). Exhibited in Table XIV are the schools that gave academic program presentations to the respondent senior high school students.

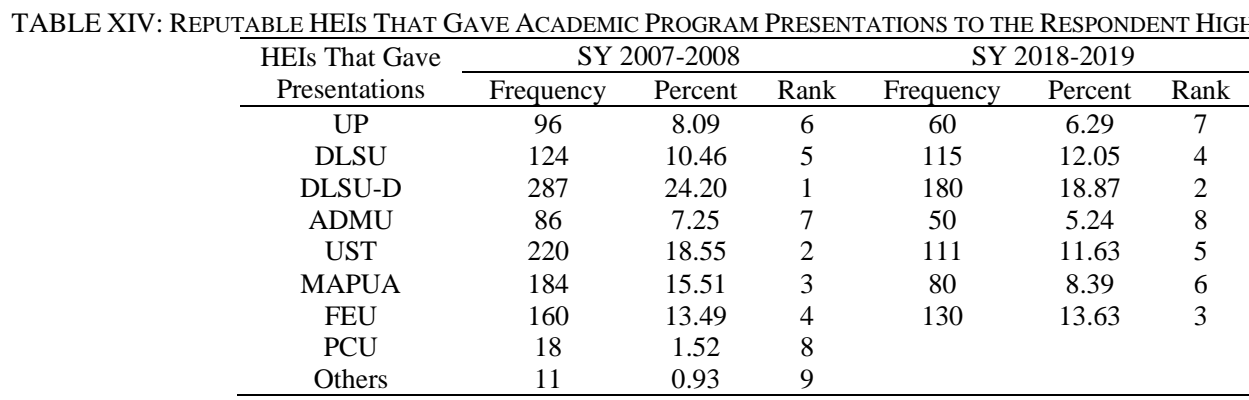

A closer look at Table XIV, SY 2007-2008 shows that ranked one among the HEIs that gave academic program presentations to the respondents was DLSU-D, as indicated by the frequency distribution of 287 or $24.20 \%$. Next in rank were the following: UST (220 or $18.55 \%$ ); MAPUA Institute of Technology (184 or $15.51 \%$ ); FEU (160 or $13.49 \%$ ); De La Salle University (DLSU) in Manila (124 or $10.46 \%$ ); UP
(96 or $8.09 \%)$; ADMU (7.25\%); and PCU (18 or 1.52\%). There were, however, other schools not included in the roster which also gave academic program presentations according to 11 respondents or $0.93 \%$.

However, Table XIV, SY 2018-2019, shows that ranked one among the HEIs that gave academic program presentations to the respondents was DLSMHSI, as indicated 
by the frequency distribution of 228 or $23.90 \%$. Next in rank were the following: DLSU-D (180 or $18.87 \%$ ); FEU (130 or $13.63 \%)$; DLSU (115 or $12.05 \%)$; UST (111 or $11.63 \%)$; MAPUA Institute of Technology (80 or $8.39 \%$ ); UP (60 or $6.29 \%$ ); and ADMU (50 or 5.24\%). Nevertheless, these academic program presentations influenced the respondent high school students on their choice of school to finish a college course.

The last of the factor that affected the respondents' choice of a college or university where to pursue their career were the features they look for in such educational institution.

Table XV shows the features these respondents were seeking.

\begin{tabular}{ccccccc}
\multicolumn{1}{c}{ TABLE XV: FEATURES LOOKED FOR IN COLLEGE BY THE RESPONDENT HIGH SCHOOL STUDENTS } \\
\hline \multirow{2}{*}{ Features looked for in college } & \multicolumn{3}{c}{ SY $2007-2008$} & \multicolumn{3}{c}{ SY 2018-2019 } \\
\cline { 2 - 7 } & Frequency & Percent & Rank & Frequency & Percent & Rank \\
\hline Course Offering & 600 & 24.63 & 1 & 510 & 53.46 & 1 \\
Image of the School & 434 & 17.86 & 2 & 94 & 9.85 & 4 \\
Licensure Examination & 336 & 13.79 & 4 & 205 & 21.49 & 2 \\
$\quad \begin{array}{c}\text { Successful Alumni } \\
\text { Complete and Up-to-Date }\end{array}$ & 258 & 10.59 & 5 & 27 & 2.83 & 3 \\
$\quad$ Facilities & 355 & 14.57 & 3 & 82 & 8.60 & 5 \\
Ease in Applying for & 216 & 8.87 & 6 & 24 & 2.52 & 6 \\
$\quad$ Admission & 179 & 7.35 & 7 & 12 & 1.25 & 7 \\
Top Caliber Faculty Line Up & 57 & 2.34 & 8 & & & \\
$\quad$ Others & $\mathbf{2 4 3 6}$ & $\mathbf{1 0 0 . 0 0}$ & & $\mathbf{9 5 4}$ & $\mathbf{1 0 0 . 0 0}$ & \\
TOTAL & & & & & &
\end{tabular}

A close reading of the data presented in Table XV shows that course offering ranked first among the features the respondents were looking for in a college or university where they desired to obtain a degree. This finding is attested by the frequency distribution of 600 or $24.63 \%$. Next in rank was the image of the school based on the frequency distribution of 434 or $17.86 \%$. Other features identified as ranked were the following: complete and up-to-date facilities (355 or $14.57 \%)$; successful alumni (258 or $10.59 \%)$; ease in applying for admission (216 or $8.87 \%$ ); and top caliber faculty line up (179 or $7.35 \%$ ). Other reasons not included in the aforementioned listing, however, were given by the remaining 57 respondents or $2.34 \%$.

The data presented in Table XV, SY 2018-2019 show that course offering also ranked first among the features the respondents were looking for in a college or university where they desired to obtain a degree. This finding is attested by the frequency distribution of 510 or $53.46 \%$. Next in rank was the licensure examination performance based on the frequency distribution of 205 or $21.49 \%$.

Other features identified by the respondents as ranked were the following: image of a school (94 or 9.85\%); complete and up-to-date facilities (82 or $8.60 \%)$; successful alumni ( 27 or $2.83 \%$ ); ease in applying for admission ( 24 or $2.52 \%$ ); and top caliber faculty line up (12 or $1.25 \%$ ).

As previously highlighted, ranked one among the features identified by the respondents was course offering. This implies that they shall be enrolling only in colleges and universities offering courses they prefer to pursue.

\section{THE STATUS OF DLSMHSI IN TERMS OF THE LEVEL OF PREFERENCE/CHOICE OF THE RESPONDENTS}

As already pointed out, high school students were influenced to a certain extent by the academic program presentations given by the representatives of reputable HEIs. Displayed in the next tables is the distribution of the respondents in terms of the most effective medium of introducing one school, which contributes to their decision to enroll. In this section, there is no information coming from SY 2007-2008, for this item was not included in the survey that time.
As reflected in Table XVI, the school visit/campus tour/open house ranked one among the most effective media of introducing the school, which in turn, contributes to the decision to enroll of the respondents, as indicated by the frequency distribution of 496 or $51.99 \%$. Next in rank were the following: Career Talk and Orientation Program (245 or $25.68 \%$ ); Advertisement thru Print \& Media (78 or $8.18 \%$ ); Competitions \& Other Activities and (35 or 3.67\%). A total of 100 respondents or $10.48 \%$ did not specify the most effective medium. Nevertheless, the school visit/campus tour/open house was considered to be the most effective medium in introducing the school, which contributed to the decision to enroll of the respondent senior high school students.

TABLE XVI: Most EFFECTIVE MEdiUM OF INTROdUCING ONE SCHOOL

\begin{tabular}{cccc}
\hline Most effective medium & Frequency & Percent & Rank \\
\hline School Visit/ Campus & 496 & 51.99 & 1 \\
Tour/ Open House & & & \\
Career Talk and & 245 & 25.68 & 2 \\
Orientation Program & 100 & 10.48 & 3 \\
$\quad \begin{array}{l}\text { Not Specified } \\
\text { Advertisement thru Print }\end{array}$ & 78 & 8.18 & 4 \\
$\quad$ \& Media & 35 & 3.67 & 5 \\
Competitions \& Other & & \\
Activities & $\mathbf{9 5 4}$ & $\mathbf{1 0 0 . 0 0}$ & \\
TOTAL & & & \\
\hline
\end{tabular}

TABLE XVII: DECISION OF THE RESPONDENT SENIOR HIGH SCHOOL STUDENTS TO TAKE UP HEALTH SCIENCES COURSES AFTER THE DLSMHSI PRESENTATION

\begin{tabular}{ccccccc}
\hline Decision & \multicolumn{3}{c}{ SY 2007-2008 } & \multicolumn{3}{c}{ SY 2018-2019 } \\
\cline { 2 - 7 } $\begin{array}{c}\text { to take } \\
\text { up health } \\
\text { sciences } \\
\text { courses }\end{array}$ & Frequency & Percent & Rank & Frequency & Percent & Rank \\
\hline Yes & 600 & 50.59 & 1 & 694 & 72.75 & 1 \\
No & 445 & 37.52 & 2 & 260 & 27.25 & 2 \\
No & 141 & 11.89 & 3 & & & \\
Response & $\mathbf{1 1 8 6}$ & $\mathbf{1 0 0}$ & & $\mathbf{9 5 4}$ & $\mathbf{1 0 0}$ & \\
TOTAL & & & & & & \\
\hline
\end{tabular}

The tabular data show that 600 or $50.59 \%$ from SY 2007 2008 and 694 or $72.75 \%$ from SY 2018-2019 answered yes on the question of whether the respondent high school students would take up health sciences courses after the DLSMHSI presentation. Four hundred forty-five (445) or 
$37.52 \%$ and two hundred sixty (260) or $27.25 \%$ responded no to the same question from SY 2007-2008 and SY 20182019, respectively. The big percentage on the Yes answer only proves that the Career Talk and Orientation Program play a very vital role in the marketing of the school and its course offerings.

Going over Table XVIII, it can be noted that 648 or $54.64 \%$ form Batch 1 and 904 or $94.76 \%$ from Batch 2 responded yes to the question of whether they would study at DLSMHSI or not. There were, however, 538 or $45.36 \%$ from Batch 1 and 50 or $5.24 \%$ from Batch 2 who answered no to the same question.
The distribution of the respondent high school students on the question of studying at DLSMHSI after the academic program presentations of the marketing team of the Institute is reflected in Table XIX.

A perusal of tabular data shows that 600 or $50.59 \%$ from SY 2007-2008 and 694 or $72.75 \%$ from SY 2018-2019 answered yes on the question of whether the academic program presentations of the marketing team of the Institute influenced them to pursue college education at DLSMHSI. Four hundred forty-five or 37.52\% from SY 2007-2008 and 260 or $27.25 \%$ from SY $2018-2019$ responded no to the same question.

TABLE XVIII: DISTRIBUTION OF THE RESPONDENT SENIOR HIGH SCHOOL STUDENTS IN TERMS OF THEIR DECISION TO STUDY AT DLSMHSI

\begin{tabular}{ccccccc}
\hline Decision to study at & \multicolumn{3}{c}{ SY $2007-2008$} & \multicolumn{3}{c}{ SY $2018-2019$} \\
\cline { 2 - 7 } DLSHSI/DLSMHSI & Frequency & Percent & Rank & Frequency & Percent & Rank \\
\hline Yes & 648 & 54.64 & 1 & 904 & 94.76 & 1 \\
No & 538 & 45.36 & 2 & 50 & 5.24 & 2 \\
TOTAL & $\mathbf{1 1 8 6}$ & $\mathbf{1 0 0}$ & & $\mathbf{9 5 4}$ & $\mathbf{1 0 0}$ & \\
\hline
\end{tabular}

TABLE XIX: DisTRIBUTION OF THE RESPONDENT High SCHOOL STUDENTS IN TERMS OF THEIR DECISION TO STUDY AT DLSMHSI AFTER THE ACADEMIC PROGRAM PRESENTATIONS OF THE MARKETING TEAM OF THE INSTITUTE

\begin{tabular}{ccccccc}
\multicolumn{2}{c}{ PROGRAM PRESENTATIONS OF THE MARKETING TEAM OF THE INSTITUTE } \\
\hline Decision to study at & \multicolumn{3}{c}{ SY $2007-2008$} & \multicolumn{3}{c}{ SY 2018-2019 } \\
\cline { 2 - 7 } DLSHSI/DLSMHSI & Frequency & Percent & Rank & Frequency & Percent & Rank \\
\hline Yes & 600 & 50.59 & 1 & 694 & 72.75 & 1 \\
No & 445 & 37.52 & 2 & 260 & 27.25 & 2 \\
No Response & 141 & 11.89 & 3 & & & \\
TOTAL & $\mathbf{1 1 8 6}$ & $\mathbf{1 0 0}$ & & $\mathbf{9 5 4}$ & $\mathbf{1 0 0}$ \\
\hline
\end{tabular}

TABLE XX: HEALTH SCIENCES COURSES PREFERRED BY THE RESPONDENT HiGH SCHOOL STUDENTS

\begin{tabular}{|c|c|c|c|c|c|c|}
\hline \multirow{2}{*}{$\begin{array}{l}\text { Preferred health } \\
\text { science courses }\end{array}$} & \multicolumn{3}{|c|}{ SY 2007-2008 } & \multicolumn{3}{|c|}{ SY 2018-2019 } \\
\hline & Frequency & Percent & Rank & Frequency & Percent & Rank \\
\hline Medicine & 171 & 14.42 & 3 & & & \\
\hline Nursing & 409 & 34.49 & 1 & 289 & 30.29 & 1 \\
\hline $\begin{array}{l}\text { Physical } \\
\text { Therapy }\end{array}$ & 198 & 16.69 & 2 & & & \\
\hline $\begin{array}{l}\text { Radiologic } \\
\text { Technology }\end{array}$ & 89 & 7.50 & 6 & 99 & 10.38 & 4 \\
\hline Midwifery & 74 & 6.24 & 7 & & & \\
\hline Dentistry & 99 & 8.35 & 5 & 20 & 2.10 & 9 \\
\hline $\begin{array}{c}\text { Medical } \\
\text { Technology }\end{array}$ & 146 & 12.31 & 4 & 210 & 22.01 & 2 \\
\hline $\begin{array}{l}\text { Pharmacy } \\
\text { Physical }\end{array}$ & & & & 126 & 13.21 & 3 \\
\hline $\begin{array}{l}\text { Therapy/Occup } \\
\text { ational Therapy }\end{array}$ & & & & 95 & 9.96 & 5 \\
\hline $\begin{array}{l}\text { Speech and } \\
\text { Language } \\
\text { Pathology }\end{array}$ & & & & 48 & 5.03 & 6 \\
\hline $\begin{array}{c}\text { Biology/Medica } \\
1 \text { Biology }\end{array}$ & & & & 37 & 3.88 & 7 \\
\hline $\begin{array}{c}\text { Biochemistry } \\
\text { TOTAL }\end{array}$ & 1186 & 100 & & $\begin{array}{c}30 \\
\mathbf{9 5 4}\end{array}$ & $\begin{array}{l}3.14 \\
100\end{array}$ & 8 \\
\hline
\end{tabular}

Reflected in Table XX are the health sciences courses preferred by the respondents, given the chance to be admitted at DLSMHSI.

A close reading of the data exhibited in Table XX, SY 2007-2008 shows that nursing is still the number one choice of the respondents if given the chance to pursue a health science course. This is substantiated by the recorded frequency distribution of 409 or $34.49 \%$. Second in rank among these courses was physical therapy, with a frequency distribution of 198 or $16.69 \%$. This was followed by medical technology ( 146 or $12.31 \%$ ) and dentistry ( 99 or $8.35 \%$ ). The rest of the health science courses respondents opted to pursue given the chance to do so were the following: radiologic technology ( 89 or $7.50 \%$ ); and midwifery (74 or $6.24 \%$ ).

The data exhibited in Table XX, SY 2018-2019 shows the same results as regards Nursing as the number one choice of the respondents if given the chance to pursue a health sciences course. This is substantiated by the recorded frequency distribution of 289 or $30.29 \%$. Second in rank among these courses was Medical Technology, with a frequency distribution of 210 or $22.01 \%$. This was followed by Pharmacy (126 or $13.21 \%$ ); Radiologic Technology (99 or $10.38 \%$ ); Occupational/Physical Therapy (95 or $9.96 \%$ ); Speech and Language Pathology (48 or 5.03\%); Biology/Medical Biology (37 or 3.88\%); Biochemistry (30 or $3.14 \%$ ); and Dentistry (20 or $2.10 \%$ ).

Survey clearly showed that Nursing is still the top choice. The priority given by the respondents for this course is definitely due to the high demand for nurses abroad. This finding corroborated with the survey conducted by GMA 7's youth-oriented show "Ka-blog" at the University belt in Metro Manila regarding the course most preferred by 
students. The survey revealed that for 2008, BS Nursing is still the most in-demand course for graduating students. Moreover, this also affirms the statistics given by the Commission on Higher Education [11] that the top three (3) courses that the graduating students prefer to take are the following: Nursing, Information Technology and Hotel and Restaurant Management.

\section{The Status OF DLSMHSI IN TERMS OF MARKETING/POSITIONING/BRANDING}

The status of DLSMHSI in terms of marketing/positioning/branding was reckoned in terms of the following: one-word description of DLSMHSI; respondents' knowledge of DLSMHSI; and what people say about the Institute.
Presented in Table XXI are data on the respondents' perception of DLSMHSI in terms of their one-word description of the institution.

Tabular data from SY 2007-2008 reveal numerous, positive perception of DLSHSI on the part of the respondents as evidenced by the one-word description they gave the Institute. Ranked one among these one-word descriptions was the adjective good, based on the frequency distribution of 129 or $21.22 \%$. This was followed by the following descriptors, as ranked: great (103 or 16.94\%); quality education (95 or $15.63 \%)$; excellent (65 or $10.69 \%)$; best $(61$ or $10.03 \%$ ); nice (42 or $6.91 \%$ ); expensive (37 or $6.09 \%$ ); competitive (23 or $3.78 \%$ ); competent (10 or $1.64 \%$ ); medical (12 or $1.97 \%$ ); popular (8 or $1.32 \%$ ); famous (6 or $0.99 \%$ ); high standard ( 5 or $0.82 \%$ ); organized (4 or $0.66 \%$ ); unique (4 or $0.66 \%$ ); and well-known (4 or $0.66 \%$ ).

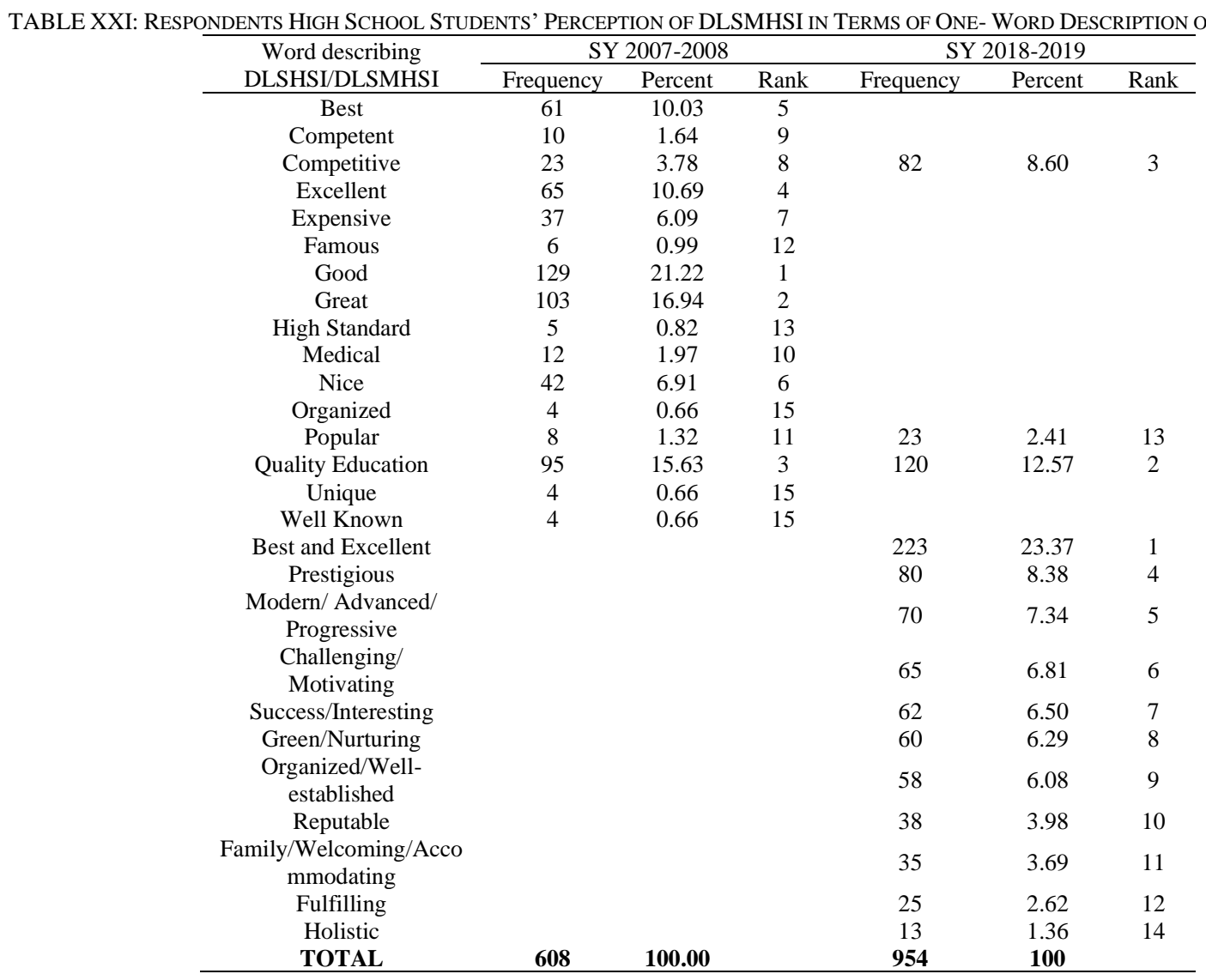

However, tabular data from SY 2018-2019 reveal that Best and Excellent ranked one among these one-word descriptions about DLSMHSI, based on the frequency distribution of 223 or $23.37 \%$. This was followed by the following descriptors, as ranked: Quality (120 or 12.57\%); Competitive (82 or $8.60 \%$ ); Prestigious (80 or $8.38 \%$ ); Modern / Advanced / Progressive (70 or $7.34 \%$ ); Challenging/Motivating (65 or $6.81 \%$ ); Success/Interesting (62 or $6.50 \%$ ); Green/Nurturing (60 or $6.29 \%$ ); Organized/Well-established (58 or $6.08 \%$ ); Reputable (38 or 3.98\%); Family / Welcoming / Accommodating (35 or 3.69\%); Fulfilling (25 or 2.62\%); Popular (23 or $2.41 \%$ ); and Holistic (13 or 1.36 ).

Respondents described DLSMHSI positively using oneword descriptor of their choice. This goes to show that they already have an image in mind of what the Institute is and its features.

Reflected in Table XXII are the data relating to how the respondents came to know things about DLSMHSI.

A perusal of Table XXII, SY 2007-2008, shows that there were numerous means/ways by which the respondents came to know DLSHSI. Ranked one among these ways or means was marketing campaign as identified by 269 respondents or $22.68 \%$. Other means by which they came to know about the Institute were the following, based on rank: family members (267 or $22.51 \%$ ); the school where they are presently enrolled (143 or $12.06 \%$ ); alumni of the school (119 or $10.03 \%)$; and peer groups (114 or $9.61 \%)$. Nonetheless, there were 82 or $6.91 \%$ who have not heard about DLSHSI. 
TABLE XXII: DisTRIBUTION OF THE RESPONDENT High SCHOOL STUDENTS IN TERMS OF HOW THEY CAME TO KNOW OF DLSMHSI

\begin{tabular}{|c|c|c|c|c|c|c|}
\hline \multirow{2}{*}{$\begin{array}{c}\text { How } \\
\text { DLSHSI/DLSMHSI } \\
\text { was known }\end{array}$} & \multicolumn{3}{|c|}{ SY 2007-2008 } & \multicolumn{3}{|c|}{ SY 2018-2019 } \\
\hline & Frequency & Percent & Rank & Frequency & Percent & Rank \\
\hline Family Members & 267 & 22.51 & 2 & 73 & 7.65 & 5 \\
\hline $\begin{array}{c}\text { Other People Talking } \\
\text { About it }\end{array}$ & 192 & 16.19 & 4 & & & \\
\hline Peer Groups & 114 & 9.61 & 6 & & & \\
\hline Alumni of the School & 119 & 10.03 & 5 & & & \\
\hline Your School & 143 & 12.06 & 3 & & & \\
\hline Marketing Campaign & 269 & 22.68 & 1 & & & \\
\hline Have not heard & 82 & 6.91 & 7 & & & \\
\hline Advertisement & & & & 231 & 24.21 & 1 \\
\hline School Visits & & & & 198 & 20.75 & 2 \\
\hline Websites & & & & 167 & 17.51 & 3 \\
\hline Search Engines & & & & 148 & 15.51 & 4 \\
\hline College Board & & & & 57 & 5.98 & 6 \\
\hline Friends & & & & 52 & 5.45 & 7 \\
\hline Facebook & & & & 26 & 2.73 & 8 \\
\hline Twitter & & & & 2 & 0.21 & 9 \\
\hline TOTAL & 1186 & 100 & & 954 & 100 & \\
\hline
\end{tabular}

Table XXII of from SY 2018-2019 shows that there were numerous means/ways by which the respondents came to know DLSMHSI. Ranked one among these ways or means was advertisement, as identified by 231 respondents or $24.21 \%$. Other means by which they came to know about the Institute were the following, based on rank: School Visits (198 or $20.75 \%$ ); Websites (167 or $17.51 \%$ ); Search Engines (148 or $15.51 \%$ ); Family Members (73 or $7.65 \%$ ); College Board (57 or $5.98 \%)$; Friends (52 or $5.45 \%)$; Facebook (26 or $2.73 \%$ ); and Twitter ( 2 or $0.21 \%$ ).

It was clearly revealed from the results for both school years that advertisement made the respondents learn many things about DLSMHSI. This only indicates the need on the part of the administrators of the Institute to sustain its marketing campaigns in the locale of this study.

Exhibited in Table XXIII, SY 2007-2008 is the respondents' perception of DLSHSI in terms of what people say about it. Data show that ranked one on the respondents' perception of DLSHSI in terms of what people say about it was quality education. This is corroborated by the frequency distribution of 389 or $32.80 \%$. Ranked second and third were high end facilities (181 or 15.26\%) and safe and very conducive for learning (115 or $9.70 \%$ ). Next in rank were the following: good performance rating in board exams (100 or $8.43 \%$ ) and well-known (83 or $7 \%$ ).

Data from SY 2018-2019 show that ranked one on the respondents' perception of DLSHSI in terms of what people say about it was quality education also. This is corroborated by the frequency distribution of 711 or $74.53 \%$. Ranked second and third were high end facilities (90 or 9.43\%) and Good Performance Rating in Licensure Exams (50 or 5.24\%). Next in rank were the following: High Employment Rate of Graduates (32 or 3.35\%); Very Expensive School/School for Rich only (20 or $2.10 \%$ ); Well-known throughout the Country and Abroad (15 or $1.57 \%$ ); Safe and Very Conducive for Learning (12 or 1.26\%); Globallycompetitive Teaching Workforce (10 or $1.05 \%$ ); Difficult to Be Admitted (8 or $0.84 \%$ ); and High Kick Out Rate (6 or $0.63 \%)$.

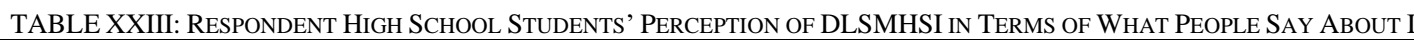

\begin{tabular}{|c|c|c|c|c|c|c|}
\hline \multirow{2}{*}{$\begin{array}{l}\text { What people say } \\
\text { about DLSHSI/ } \\
\text { DLSMHSI }\end{array}$} & \multicolumn{3}{|c|}{ SY 2007-2008 } & \multicolumn{3}{|c|}{ SY 2018-2019 } \\
\hline & Frequency & Percent & Rank & Frequency & Percent & Rank \\
\hline Quality Education & 389 & 32.80 & 1 & 711 & 74.53 & 1 \\
\hline $\begin{array}{l}\text { High End Facilities } \\
\text { Safe and Very }\end{array}$ & 181 & 15.26 & 2 & 90 & 9.43 & 2 \\
\hline $\begin{array}{l}\text { Conducive for } \\
\text { Learning }\end{array}$ & 115 & 9.70 & 3 & 12 & 1.26 & 7 \\
\hline $\begin{array}{l}\text { Globally Competitive } \\
\text { Workforce }\end{array}$ & 62 & 5.23 & 8 & 10 & 1.05 & 8 \\
\hline $\begin{array}{l}\text { Well Known } \\
\text { throughout the }\end{array}$ & 83 & 7.00 & 5 & 15 & 1.57 & 6 \\
\hline $\begin{array}{l}\text { Country and Abroad } \\
\text { No Impression }\end{array}$ & 17 & 1.43 & 11 & & & \\
\hline $\begin{array}{l}\text { Good Performance } \\
\text { Rating in Board } \\
\text { Exams }\end{array}$ & 100 & 8.43 & 4 & 50 & 5.24 & 3 \\
\hline $\begin{array}{l}\text { High Employment } \\
\text { Rate of Graduates }\end{array}$ & 74 & 6.24 & 7 & 32 & 3.35 & 4 \\
\hline $\begin{array}{l}\text { Difficult to Be } \\
\text { Admitted } \\
\text { Very Expensive }\end{array}$ & 76 & 6.41 & 6 & 8 & 0.84 & 9 \\
\hline $\begin{array}{l}\text { School/ School for } \\
\text { Rich only }\end{array}$ & 51 & 4.30 & 9 & 20 & 2.10 & 5 \\
\hline $\begin{array}{c}\text { High Kick Out Rate } \\
\text { TOTAL }\end{array}$ & $\begin{array}{c}38 \\
1186 \\
\end{array}$ & $\begin{array}{c}3.20 \\
\mathbf{1 0 0 . 0}\end{array}$ & 10 & $\begin{array}{c}6 \\
954 \\
\end{array}$ & $\begin{array}{c}0.63 \\
\mathbf{1 0 0 . 0}\end{array}$ & 10 \\
\hline
\end{tabular}


Data clearly point to the reality that DLSMHSI is known to many people in owing to its quality education and good performance in the various fields of health sciences. It can be inferred also from the foregoing findings that DLSMHSI has already positioned itself in the area relative to its program offerings.

\section{FINDINGS, CONCLUSIONS, AND RECOMMENDATIONS}

\section{A. Summary of Findings}

The salient findings of the study are presented following the sequence of the problems.

\section{1) 1. Schools and Courses Preferred by High School Students}

\section{a) SY 2017-2018}

Schools preferred by the respondents were the following: De La Salle Health Sciences Institute (DLSHSI); University of the Philippines; Ateneo De Manila University; University of Sto. Tomas; Adamson University; Far Eastern University; and Philippine Christian University. DLSHSI, however, ranked one among these schools, based on the frequency distribution of 300 or $25.30 \%$. Their preference for the aforementioned schools started when they were already on their senior year in high school as indicated by the frequency distribution of 489 or $41.23 \%$.

As to the courses preferred by the respondents, Hotel and Restaurant Management (HRM) ranked one based on the frequency distribution of 398 or $33.56 \%$. This was followed by business courses (246 or $20.74 \%$ ); engineering (189 or $15.94 \%)$; health sciences (150 or $12.65 \%$ ); and information technology (100 or $8.43 \%)$. Survey disclosed that their course preference became very certain when they were already about to graduate in high school as indicated by the frequency distribution of 532 or $44.86 \%$.

\section{b) $S Y 2018-2019$}

Schools preferred by the respondents were the following: De La Salle Medical and Health Sciences Institute (DLSMHSI); University of the Philippines (UP); University of Sto. Tomas (UST); De La Salle University-Dasmariñas (DLSU-D); Far Eastern University (FEU); University of the East (UE); Centro Escolar University (CEU); Emilio Aguinaldo College (EAC); Lyceum of the Philippines University (LPU); and Pamantasan ng Lungsod ng Maynila (PLM). DLSMHSI, however, ranked one among these schools, based on the frequency distribution of 220 or $23.06 \%$.

As to the courses preferred by the respondents, Nursing ranked one based on the frequency distribution of 150 or $15.72 \%$. This was followed by Medical Technology (147 or $15.41 \%$ ); Physical Therapy (132 or $13.84 \%$ ); Pharmacy (94 or $9.85 \%$ ); Radiologic Technology (92 or $9.64 \%$ ); Other courses such as Humanities, Business and Engineering (75 or $7.86 \%$ ); Occupational Therapy (70 or $7.34 \%$ ); Other Allied Health Courses (60 or 6.29\%); Speech and Language Pathology (47 or $4.93 \%$ ); and Biochemistry (38 or $3.98 \%$ ). Survey disclosed that Nursing was on top of the courses preferred by the respondent senior high school students, which could probably be attributed to the perceived employability abroad.

\section{2) Possible Reasons for Choosing the School and the Course}

\section{a) SY 2007-2008}

Survey revealed that applicability to their chosen career surfaced as the leading reason given by the respondents in their preferred course to pursue after high school. This finding was inferred from the recorded frequency distribution of 317 or $26.73 \%$. The other reasons given by the respondents based on rank were the following: high paying job opportunities (300 or 25.30\%); in demand abroad (275 or $23.19 \%)$; influenced by parents (109 or 9.19\%) and affordability of the course (96 or $8.09 \%$ ). Ranked last among the reasons given by the respondents was influenced by friends (89 or $7.50 \%)$.

Factors that contributed to their choice of school where to obtain a college degree after high school included the following: the decision maker on where to study; academic program presentations given prior to graduation by college authorities; and features students look for in a college or university where they intend to study.

As to the choice of school where to complete college education, survey revealed the students themselves are the ones making decisions regarding where they intend to pursue a course of their choice. This finding was confirmed by the frequency distribution of 878 or $74 \%$.

Another factor that can explain the respondents' choice of school where to study was the presentation given by reputable Higher Education Institutions (HEIs) in the Cavite, Laguna, Batangas, Rizal, and Quezon (CALABARZON) Provinces and National Capital Region. Survey revealed that DLSU-D ranked first among those institutions identified by the respondents as giving academic program presentations in their respective schools.

Another factor to reckon with was the feature students look for in the college or university where to pursue their career. Apparently, course offering surfaced as the number one factor they were looking for in an institution of higher learning where they wanted to enroll. This finding was based on the frequency distribution of 600 or $24.63 \%$. The other features they are looking for in a preferred school as ranked were the following: image of the school (434 or $17.86 \%$ ); complete and up-to-date facilities (355 or 14.57\%); performance of graduates in the licensure examination (336 or $13.79 \%$ ); successful alumni (258 or $10.59 \%)$; ease in applying for admission (216 or $8.87 \%$ ); and top caliber faculty line-up (179 or $7.35 \%$ ).

\section{b) $S Y 2018-2019$}

Survey revealed that applicability to their chosen career path also surfaced as the leading reason given by the respondents in their preferred course to pursue after senior high school. This finding was inferred from the recorded frequency distribution of 720 or $75.47 \%$. The other reasons given by the respondents based on rank were the following: influenced by parents (76 or $7.97 \%$ ); in demand abroad (56 or $5.87 \%$ ); high paying job opportunities (53 or $5.56 \%$ ); influenced by friends/peer/classmates (15 or $1.57 \%$ ); and affordability of the course ( 3 or $0.31 \%$ ).

Factors that contributed to their choice of school where to obtain a college degree after senior high school included the following: the decision maker on where to study; academic 
program presentations given prior to graduation by college authorities; and features students look for in a college or university where they intend to study.

As to the choice of school where to complete college education, survey revealed the students themselves are the ones making decisions regarding where they intend to pursue a course of their choice. This finding was confirmed by the frequency distribution of 747 or $78.30 \%$.

Another factor that can explain the respondents' choice of school where to study was the presentation given by reputable Higher Education Institutions (HEIs). Survey revealed that DLSMHSI ranked first among those institutions identified by the respondents in terms of giving academic program presentations in their respective schools.

Another factor to reckon with was the feature students look for in the college or university where to pursue their career. Apparently, course offering surfaced as the number one factor they were looking for in an institution of higher learning where they wanted to enroll. This finding was based on the frequency distribution of 510 or $53.46 \%$. The other features they are looking for in a preferred school as ranked were the following: licensure examination performance (205 or $21.49 \%$ ); image of the school (94 or $9.85 \%$ ); complete and up-to-date facilities ( 82 or $8.60 \%$ ); performance of graduates in the licensure examination (336 or $13.79 \%$ ); successful alumni (27 or $2.83 \%$ ); ease in applying for admission (24 or $2.52 \%$ ); and top caliber faculty line-up (12 or $1.25 \%$ ).

3) The Status of DLSMHSI in Terms of the Level of Preference/Choice of the Respondents

a) SY 2007-2008

Survey revealed that 648 or $54.64 \%$ were willing to study at DLSHSI. Given the chance to pursue a career at DLSHSI, 600 out of 1,186 or $50.59 \%$ responded yes to the question of enrolling at the Institute.

As to the courses they shall pursue given the opportunity to be admitted at DLSHSI, survey showed that nursing ranked first among the courses preferred by the respondents based on the frequency distribution of 409 or $34.49 \%$. Other health science courses preferred by the respondents as ranked were the following: physical therapy (198 or 16.69\%); medicine (171 or $14.42 \%)$; medical technology (146 or $12.31 \%$ ); dentistry (99 or $8.35 \%$ ); radiologic technology (89 or $7.50 \%$ ); and midwifery (74 or $6.24 \%$ ).

b) SY 2018-2019

Survey revealed that 694 respondents or $72.75 \%$ were willing to take up health sciences courses after the DLSMHSI presentation and same number and percentage were willing to study at DLSMHSI after the Academic Presentations of the Marketing Team of the Institute. Given the chance to pursue a career at DLSMHSI, 904 out of 954 or $94.76 \%$ responded yes to the question of enrolling at the Institute.

As to the courses they shall pursue given the opportunity to be admitted at DLSMHSI, survey showed that Nursing also ranked first among the courses preferred by the respondents based on the frequency distribution of 289 or $30.29 \%$. Other health sciences courses preferred by the respondents as ranked were the following: Medical Technology (210 or $22.01 \%$ ); Pharmacy (126 or $13.21 \%$ ); Radiologic Technology (99 or $10.38 \%)$;
Occupational/Physical Therapy (95 or $9.96 \%$ ); Speech and Language Pathology (48 or 5.03\%); Biology/Medical Biology (37 or $3.88 \%$ ); Biochemistry (30 or $3.14 \%$ ); and Dentistry (20 or $2.10 \%$ ).

\section{4) The Status of DLSMHSI in Terms of Marketing/Positioning/Branding}

The status of DLSMHSI in terms of marketing/positioning/branding was reckoned in terms of the following: one-word description of DLSMHSI; respondents' knowledge of DLSMHSI; and what people say about the Institute.

\section{a) SY 2007-2008}

Respondent high school students perceived DLSHSI as good (129 or $21.22 \%)$, great (103 or $16.94 \%)$, one with quality education (95 or 15.63\%); excellent (65 or $10.69 \%$ ), and best (61 or $10.03 \%$ ). Other one-word descriptors given by the respondents regarding DLSHSI included the following: nice; expensive; competitive; competent; medical; famous; with high standard; organized; unique; and well-known.

Respondents, however, came to know DLSHSI through various means. Survey showed that the leading source of their information about the Institute was through the marketing campaigns undertaken by the marketing team of the Institute, based on the frequency distribution of 269 or $22.68 \%$. Nonetheless, the other means by which they came to know about the Institute were the following, based on rank: from family members; the school where they are presently enrolled; alumni of the school; and peer groups.

In terms of what people say about DLSHSI, quality education ranked first among those identified by the respondents based on the frequency distribution of 389 or $32.80 \%$. Other responses given by the respondents based on rank were the following: high end facilities; safe and very conducive for learning; good performance rating in board exams; and well-known; difficult to be admitted; high employment rate of graduates; globally competitive; very expensive school; and high kick out rate.

\section{b) SY 2018-2019}

Respondent high school students perceived DLSMHSI as Best and Excellent (223 or 23.37\%); Quality (120 or $12.57 \%$ ); Competitive (82 or $8.60 \%$ ); Prestigious (80 or $8.38 \%$ ); Modern/Advanced/Progressive (70 or $7.34 \%$ ); Challenging/Motivating (65 or $6.81 \%$ ); Success/Interesting (62 or $6.50 \%)$; Green/Nurturing $(60$ or $6.29 \%)$; Organized/Well-established (58 or $6.08 \%$ ); Reputable (38 or $3.98 \%$ ); Family/Welcoming/Accommodating (35 or 3.69\%); Fulfilling (25 or 2.62\%); Popular (23 or $2.41 \%$ ); and Holistic (13 or 1.36$)$.

Respondents, however, came to know DLSMHSI through various means. Survey showed that the leading source of their information about the Institute was through the advertisement produced by the marketing team of the Institute, based on the frequency distribution of 231 or $24.21 \%$. Nonetheless, the other means by which they came to know about the Institute were the following, based on rank: school visits; websites; search engines; family members; college board; friends; Facebook; and Twitter.

In terms of what people say about DLSMHSI, quality education ranked first among those identified by the 
respondents based on the frequency distribution of 711 or $74.53 \%$. Other responses given by the respondents based on rank were the following: high end facilities; good performance rating in licensure exams; high employment rate of graduates; very expensive school/school for rich only; well-known throughout the country and abroad; safe and very conducive for learning; globally competitive teaching workforce; difficult to be admitted; and high kick out rate.

\section{B. Conclusions of the Study}

On account of the foregoing findings, the following conclusions were drawn:

1) High school students are indeed sure enough of the school and the course to take after completing their high school education.

2) On the whole, their choice of course to pursue depends on its perceived applicability to their chosen career. On the other hand, their choice of school where to complete college education rests on numerous factors such as who makes decision on where to study, academic program presentations provided by various colleges and universities and the features they look for in a higher education institution, and the general image and record of the schools.

3) DLSMHSI is an institution acceptable to the respondents in terms of pursuing health sciences-related courses, with Nursing as the leading health sciences program preferred by the high school students both from the studies conducted in SY 2007-2008 and SY 2018-2019. School Visit/Campus Tour/Open House is considered to be the most effective medium of introducing the school, which contributes to the decision of the high school students to enroll. However, this platform may change given the current situation due to the COVID-19 pandemic.

4) On the whole, DLSMHSI has outsmarted the other higher education institutions offering health sciences programs as reflected in the results of the study particularly owing to its positive image to the community it serves.

\section{Recommendations}

Based on the significant findings and conclusions of the study, the following recommendations are offered:

1) The survey may be replicated using the science high schools in the country in order to further lend credence to the salient findings of this study. The researcher is giving potential researchers an open access to this paper and allowing them to replicate this study provided that proper citations shall be done. All related literatures and studies, theoretical framework and other parts may be used by future researchers.

2) As the students' themselves were noted to be a crucial deciding factor on what course to enroll and where to enroll it and given the current situation we have due to the pandemic, the marketing team of DLSMHSI should continue to provide more virtual activities, e.g. virtual open house, competitions, virtual campus tours, robotics exhibition, and other training programs for potential students including their advisers and teachers to entice students to pursue any of the health sciences courses it offers.

3) DLSMHSI should sustain its creative marketing strategies as this scheme is proven effective and helpful in inspiring and encouraging high school students to pursue their career in DLSMHSI. The alumni of the school particularly the board topnotchers and former scholars should also be tapped in this activity, as they are the concrete examples of what it can do for those who decide to obtain a college degree in a reputable and prestigious higher education institution.

4) DLSMHSI may consider offering other creative undergraduate and graduate health sciences-related courses in the future to capture more potential students to study in the City of Dasmariñas instead of going to Metro Manila. This is also in preparation for the application for the University Status of the Institute.

5) The Institute should continuously improve its conduct of Home-Based Alternative Learning Modalities (HBALMs) through efficient and effective management of the Learning Management System.

6) DLSMHSI may also intensify its international marketing and recruitment of students and forge more agreements and partnerships particularly in other Middle East Countries, ASEAN Region and other parts of the world to sustain its enrollment in the coming years and to enhance its international presence necessary for the ASEAN Integration.

\section{REFERENCES}

[1] Campbell, A. (2017). What is choice and why does it matter? Retrieved 28 September 2020 from https://lifeichoose.com/what-ischoice-and-why-does-it-matter/.

[2] Wolpert-Gawron, H. (2018). Why choice matters to student learning.

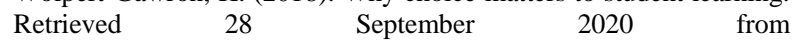
https://www.kqed.org/mindshift/52424/why-choice-matters-tostudent-learning.

[3] Knight, S. (2016). Why students should choose their own classes.

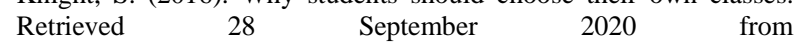
https://www.thesunchronicle.com/vip/opinion/columns/guestcolumn-why-students-shouldchoose-their-ownclasses/article_9b794965-5d99-55c0-9890-fa66d23ce407.html58.

[4] Fizer, D. (2013). Factors Affecting Career Choices of College Students Enrolled in Agriculture. A Master's Thesis. University of Tennessee, Martin. USA.

[5] Holland, J. (1997). Theory of Career Choice. Retrieved 2008 from https://www.careerkey.org/fit/personality/hollands-theory-of-careerchoice

[6] Cabanias, J.O. (2008). The schools and courses preferred by the high school graduating students from the different schools in METRO MANILA and CALABARZON Areas, School Year 2008-2009 and their implications to the marketing programs of De La Salle Health Sciences Institute.

[7] Cabanias, J. O. (2020). School and course preference of senior high school students, school year 2018-2019: Their implications to the marketing program of De La Salle Medical and Health Sciences Institute.

[8] Barnier, B. and Ganti, A. (2020). What is rational choice theory?

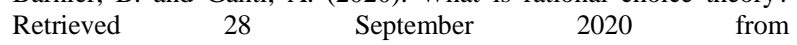
https://www.investopedia.com/terms/r/rational-choice-theory.asp.

[9] Krull, S, "School Selection Patterns Choice and Traditional Public Schools through the Lenses of Rational Choice Theory and Behavioral Economics Theory" (2016). Theses and Dissertations. 1380. https://dc.uwm.edu/etd/1380.

[10] Penedilla, J. and Rosaldo, L. (2017). Factors affecting career preferences among senior high school students in Tacloban City. Eastern Visayas State University: Tacloban City, Philippines.

[11] Top 3 Courses Preferred by Graduating Students according to Commission on Higher Education retrieved from GMA's 24 Oras, GMA Network, Inc.

[12] Enrollment Statistics retrieved from The Registrar. De La Salle Medical and Health Sciences Institute (2018). City of Dasmariñas, Cavite.

[13] Hernando (2020). Retrieved https://news.mb.com.ph/2017/08/08/ched-lists-popularcoursesbusiness-ad-education-tops/. 
[14] Admission Statistics retrieved from Lasallian Admission and Scholarship Opportunities. De La Salle Medical and Health Sciences Institute (2019). City of Dasmariñas, Cavite.

[15] Asian Institute of Developmental Studies, Inc. (2008)

[16] Cabanias, J. O. (2007). SAdO Reports 2004-2007. A three-year comprehensive documentary. De La Salle University-Dasmariñas, City of Dasmariñas, Cavite.

[17] Commission on Higher Education Report on the top five disciplines in terms of enrollment for academic year (AY) 2016-2017.Retrieved 20 February 2020.

[18] Dzafir, C. (2008). The mega education consultants.

[19] "Ka-blog", GMA Network, Inc. Most Preferred Courses by Teenagers (September 20, 2008).

[20] Olenski, S. (2018). 5 Ways to Implement Education-Based Marketing.

[21] Smart et al., (2000). Academic Disciplines by Holland Types.

[22] Stevens, J. (2020). Retrieved from HostingFacts.com

[23] The ICEF. Connect. Recruit. Grow. Bonn, Germany (2008).

[24] The Schoolguide Magazine published by SG Advertising and Publications, Inc. (2007)

Prof. Dr. Juanito O. Cabanias, is currently the Vice Chancellor for Academics of De La Salle Medical and Health Sciences Institute. He is also a Professor of Literary Theory in the Teaching of Literature of the College of Liberal Arts and Communication Graduate Studies and Executive Communication of the College of Business Administration and Accountancy Graduate Studies of De La Salle University-Dasmarinas. He was awarded Most Outstanding Faculty Member of Languages and Literature Department of the College of Liberal Arts in 2004 and Most Outstanding Faculty Member of the College of Business Administration and Accountancy Graduate Studies of DLSU-D in 2017, 2018 and 2019. He also received the Young Patriot Achiever Award in 2006 given by the DLSU Alumni Association Dasmariñas Chapter.

Prof. Dr. Cabanias represented the De La Salle Medical and Health Sciences Institute in the Lasallian Higher Education Leadership Program sponsored by the International Association of Lasallian Universities in Rome, Italy on June $02-17,2012$. He was appointed as the first dean of the College of Humanities and Sciences of De La Salle Health Sciences Institute in 2014 and the first non- Medical Doctor Vice Chancellor for Academics of DLSMHSI. 